\title{
DISPLAY PRODUCT TRAINING TO ENHANCE TOURISM VILLAGE ATTRACTION AT DUSUN WANGUN- BANDUNG
}

\author{
Yunida Sofiana ,Titik Endahyani, Religiana Hendarti \\ Bina Nusantara University, Indonesia. \\ ysofiana@binus.edu
}

\begin{abstract}
In the area of dusun Wangun, has a lot of tourism potential that can be made for an attractive tourist destination, such as tours to Mount Puntang, pine forest tours and their environmental attractiveness. To promote the existing tourism potential, the PKK communities in Dusun Wangun have made souvenir products inspired by their region's natural products (coffee, sorghum, etc.). The Souvenir products that they have made are projected to help promote regional tourism as well as increase community income in their area. To help promote these souvenirs products, it is necessary to have promotional tools that also can be used as promotional tools to enhance tourism village attraction. Promotion tools includes a place to display souvenir products that they have made. The methodology of this research uses literature review data on the form of media promotion and product display, field surveys and interviews, training, prototyping and design implementation. The result of this training was an increase in the knowledge of the community specifically youth groups in the Dusun Wangun, to display their product and their manufacture to support tourism promotion in their area.
\end{abstract}

Keyword; Dusun Wangun, Rural Empowerment, Tourism Village, Souvenir Products, Display Product

\section{Introduction}

The Dusun Wangun located in the village of Pasirmulya is one of the settlements that has a lot of tourism potential that can be developed. In addition to its environmental attraction, the village located at the end of Mount Puntang has also succeeded in producing coffee that has a distinctive taste and has won an international award. With the aim of supporting the tourism promotion program to the village, training has been carried out to the community in dusun wangun, especially to PKK communities by providing sewing training applications to make souvenirs that raise the characteristics of dusun wangun (Endahyani and Sofiana, 2018). The training has resulted in a variety of souvenirs including bags, wallets, key chains, brooches made from flannel cloth and fabric. Various souvenirs that have been made are expected to increase the income of PKK communities and increase the family welfare.

To introduce souvenirs of their products to the wider community and tourists, it is necessary to carry out a promotional strategy for the souvenirs. One of the ways is by providing a product display training arrangement to the youth community in the dusun Wangun. The training will be applied to making carts that will be used as a place to sell souvenirs that have been made. The cart, aside from being a place of sale, will be used as a promotional souvenir for the dusun Wangun. The purpose of this training is to improve community welfare through the promotion of souvenir products. So that the souvenirs of PKK mothers from Dusun Wangun Village can be promoted more broadly so that they can improve their welfare and as a tourism.

\section{Method}

The training method begun by conducting field observations and surveys to see the potential of materials and human resources, as well as conducting interviews with partners and the community of dusun wangun. As well as, the collection of literature data for cart designs and booth displays that will be used to design booths that are suitable for the products, packaging and souvenirs that have been made. From these data, the training concept of display product management and cart design was designed to be provided to the people of dusun Wangun. The training will be carried out in stages, starting with an introduction to the promotion of the form of a cart and display booth, followed by the process of designing a cart and display booth, and finally the training on making a cart (prototype). From the training series, an evaluation will be conducted by giving questionnaires to the participants to improve the training ahead. With this training, it is expected that the community in dusun Wangun can have knowledge and experience in displaying products in an interesting way and can make a cart that can support the display of the product. So as to increase the sale of souvenirs that they have produced. 


\section{Result and Discussion}

In the previous training, the PKK communities in dusun Wangun had succeeded in making souvenir products inspired by the natural assets, such as coffee, fruit, leaves and flowers. Souvenir products include bags (tote bags, small bags), wallets, key chains, pins, coasters. Souvenir products created by the PKK communities in dusun Wangun have the potential to become a typical product of dusun Wangun tourism, seen from the many inspirational designs and shapes they take are part of the environment and nature around dusun Wangun.
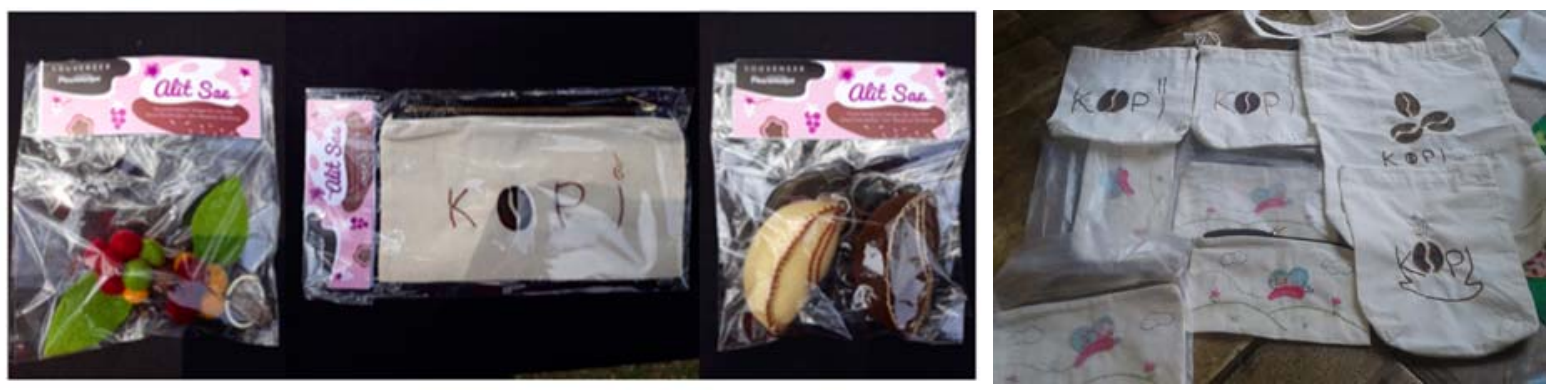

Picture1. Souvenir Products Dusun Wangun (doc. AY \& YS)

Souvenir Product Promotion Strategy

One of the benefits of developing the village into a tourist village is to provide promotional avenues for marketing existing local products, including souvenir products. This is because with the increasingly well-known village as a tourist spot, the results of local products will be well known as tourist villages.

The souvenir is an integral part of the travel experience and to preserve and commemorate such experiences, most tourists return home with souvenirs. Souvenirs may take the shape of t-shirts, genuine handcrafted products, antiques, key chains, landmark miniature replicas, or other objects. According to Collins, Noga and Zins (2011) souvenirs serve as travel experience symbols after the journey and evoke memories.

There are several steps that can be done to promote local products, together with souvenir products by determining which products have the potential to become a reliable product. Potential products that are the mainstay of dusun Wangun include Puntang coffee produced from the community around dusun Wangun. Puntang Coffee is quite well known by the public because of its success in winning international level coffee competitions. This achievement can be used as a promotion to elevate other products in dusun Wangun by raising the name of Puntang Coffee that has been known. Thus, the promotion that will be carried out through the tourism village and Puntang coffee can provide a characteristic for dusun Wangun. In addition, the existence of potential local products can also help villagers distribute their products to a wider market.

Thus, the step of promoting local products through this tourism village has a positive impact on the economy of the local community and reduces production costs for raw materials. Because local products will later be expected to be the hallmark of a tourism village that can be promoted, this is why it is necessary to have quality control over the products promoted. As a step to promote local products through tourism villages, it can be started by improving the quality of its human resources through a series of training in order to improve the processing of raw materials in order to become high quality products.

Products from the tourist village are part of the experience of visitors while doing activities and visiting the tourist village. The experience consists of what they see (something to see), what they do (something to do) and what they buy (something to buy). Therefore, the steps that can be taken in promoting the village tourism is by finding, recognizing or identifying what can be seen, done and purchased by visitors in the tourist village.

To promote souvenir products, there are stages that can be done, among others, by identifying products in the tourist village, including by recording as much potential as possible what is owned by the dusun Wangun. The usual things done by residents in the dusun Wangun, such as seeing farmers picking coffee beans, going to rice fields, processing sorghum, may be in their eyes as villagers it is part of their daily activities, but it can be something extraordinary in the eyes of visitors from the city. The characteristics of the daily life of the residents of dusun Wangun are an inspiration for the souvenir products they make.

The next step is to think in an innovative way, which is to make something that does not exist in the dusun Wangun, such as making a viewing post for selfies, making resting facilities such as wooden benches and tables, making scenic platforms, making attractive shopping carts for selling and promoting tourism. 


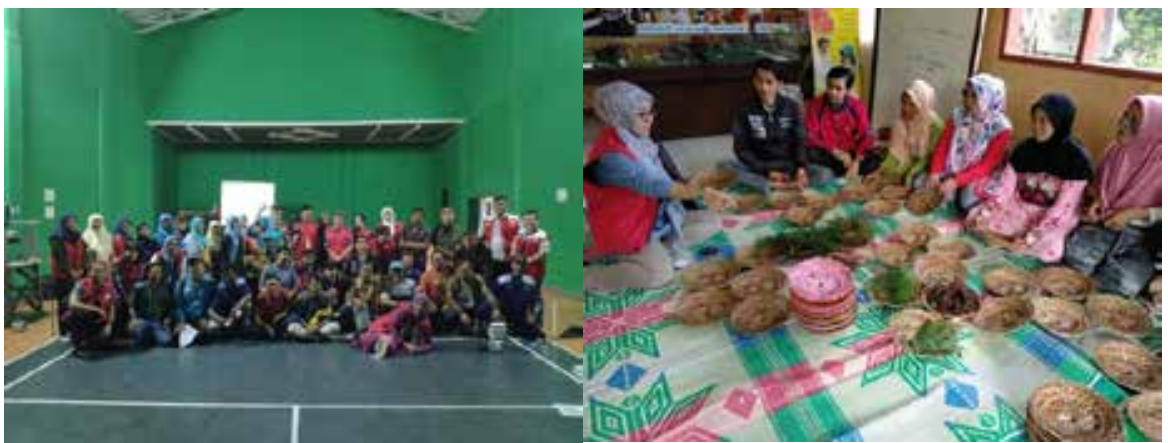

Picture 2. Community Training (doc.TI)

Booth Display as Media Promotion

One of the ways that can be applied by marketers in marketing their products is to use a booth display. Booth display has a lot of uses in the field of product promotion, usually the booth display is known as a modern cart because of the uniqueness of the many motifs in form. The design and material of the booth changes according to the function, location and target market segment. The booth design plan to be designed is to design a booth with a lot of material available around the dusun Wangun area including pine and bamboo. The design of the booth will be designed with a simple form and easy to make but still has a power of attraction. Because of the many souvenirs in the form of small so it needs to be made a storage area that is sufficient to accommodate the small product such as box made of weaving bamboo or rattan.

One of the promotion media through booth design media is as promotion development and how to promote products in the minds of consumers more attractively. There are several goals that can be achieved relating to products sold, among others, to increase brand awareness, brand equity, and brand loyalty. Booth is a countershaped place that is used to deliver, sell products to the general public. Usually placed outside or indoors like on the roadside, parks, malls and others. To expand and attract consumers, booths can be placed in strategic places that can attract the attention of visitors. Plans to place booths in the future will be placed in several tourist locations in Dusun Wangun and malls in the Bandung area.

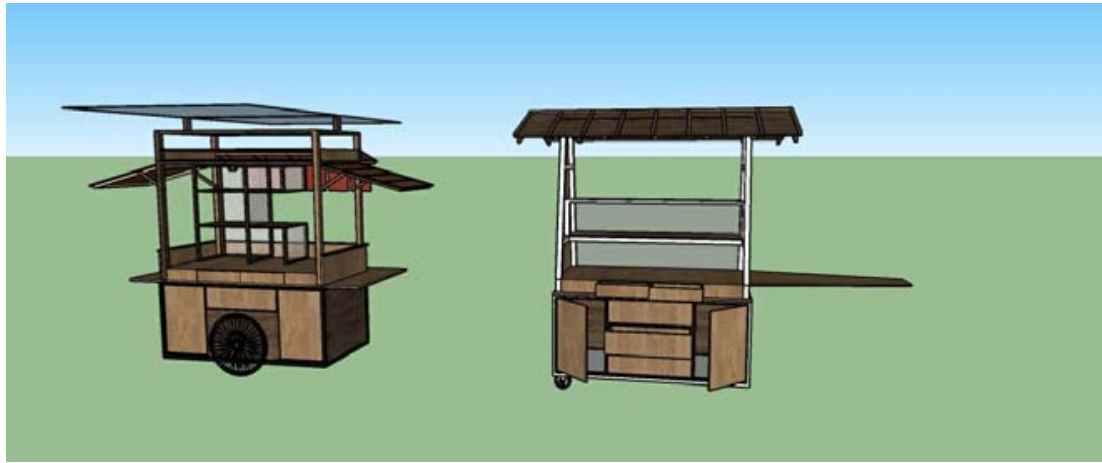

Picture 3. Design Display Booth (doc. RH)

\section{Conclusion}

It is longed that the booth design can create awareness among consumers that souvenirs from Dusun Wangun are no longer thoughtless souvenirs but have become quality souvenirs. Through the sale of the souvenir, it is expected that it will be able to introduce dusun Wangun and tourism promotion products and products from dusun Wangun to the people around Bandung and also outside Bandung.

\section{References}

Collins-kreiner, Noga and Yael Zins (2011) "Tourists and Souvenirs: Changes through Time, Space and Meaning," Journal of Heritage Tourism, vol. 6, no. 1, p. 17-27.

Kim, Soyoung and Mary A. Littrell (1999) "Predicting Souvenir Purchase Intentions," Journal of Travel Research, vol. 38, no. 2, p. 153-162. 
Lise Héroux and Nancy J. Church. (2014) Marketing Strategies of Gift and Souvenir Shops in Canada and the United States, Téoros [Online], 33, 2 |2014, Online since 12 January 2016, connection on 08 August 2019. URL : http://journals.openedition.org/teoros/2653

Rosenbaum, Mark S. and Daniel L. Spears (2005) "Who Buys What? Who Does What? Analysis of CrossCultural Consumption Behaviors Among Tourists in Hawaii," Journal of Vacation Marketing, vol. 11, no. 3, p. 235-247.

Solberg Søilen, K. (2013). Exhibit Marketing and Trade Show Intelligence: Successful Boothmanship and Booth Design. Springer Science \& Business Media.

Indahyani, Titi, Sofiana, Yunida, and Yuniarso, Ari. (2018) Reinforcement Identity of Tourism Village at Dusun Wangun-Bandung. ICCD, Vol.1, no. 1, p.290-294. URL : https://iccd.asia/ojs/index.php/iccd/article/view/44/44 